Childhood, Severed Heads, and the Uncanny:

\title{
Freudian Precursors
}

Sally Shuttleworth

University of oxford

In his 1905 essay on Infantile Sexuality, Freud notes that writers interested in the characteristics and reactions of the adult mind, "have devoted much more attention to the primaeval period which is comprised in the life of the individual's ancestors -- have, that is, ascribed much more influence to heredity -- than to the other primaeval period, which falls within the lifetime of the individual himself -- that is, to childhood" (173). By cutting through the amnesia which "turns everyone's childhood into something like a prehistoric epoch," (176) he aims to unveil the sexuality which lies at the heart of childhood, and hence, adult life.

Freud draws here on the concatenation of late nineteenthcentury anthropological, psychological, and evolutionary biological theories which sought to find in the living child the secrets of the development of the race. He compresses and condenses history into the space of the single life, with childhood holding the key which will unlock the inexplicable in adult experience. Yet the notion of prehistory is not 
merely analogical. Freud continues in his later work to operate a dual or layered theoretical framework, with childhood functioning as the condensed expression of both personal and racial history. Thus Totem and Taboo of 1913, or to give it its full title, some Points of Agreement between the Mental Lives of Savages and Neurotics, actually uses children, far more than neurotics, to explore the ways in which "atavistic vestiges" of primitive life survive in the European psyche. As Freud notes in the Preface, an attempt has been made in Totem and Taboo, "to deduce the original meaning of totemism from the vestiges remaining of it in childhood -- from the hints of it which emerge in the course of the growth of our own children" (xiv). Childhood bears witness both to a lost personal and historical past.

This dual framework is clearly in evidence in Freud's famous 1919 essay on "The Uncanny" where he argues that, "an uncanny experience occurs either when infantile complexes which have been repressed are once more revived by some impression, or when primitive beliefs which have been surmounted seem once more to be confirmed" (249). In reality, he notes, the two forms are not easily differentiated, since "primitive beliefs are most intimately connected with infantile complexes, and are, in fact, based on them" (249). In a self-defining circle, the child exhibits vestiges of primitive behaviour, which are in turn a form of infancy. 
Freud's theory of the uncanny, or unheimlich (unhomely), is based in substance, although not interpretation, on a 1906 essay by Ernst Jentsch, "On the Psychology of the Uncanny," and both draw strongly on nineteenth-century anthropological theories of animism, which were first articulated with reference to primitive cultures. For Jentsch, the uncanny is caused by the psychical uncertainty aroused when the homely, or familiar, is unsettled. In a passage quoted by Freud (226), he argues that one of the most powerful causes of the uncanny is "doubt as to whether an apparently living being is animate and, conversely, doubt as to whether a lifeless object may not in fact be animate" (11). Prime examples would be horror caused by a dead body, or death's head, or, for the superstitious, when "the head of a pillar. . . comes alive by means of hallucination" $(15,13)$ According to Jentsch, "women, children and dreamers," (13) or those who are closest to prerational forms of animism, are most susceptible to the uncanny .

Freud draws on Jentsch's material, but adds in a further definition of the unheimlich: not only the unfamiliar, but also that which is hidden. His theory of the uncanny which, inevitably, gives a foundational role to the castration complex, is based on a return, in adulthood, of repressed experiences, or the reawakening of the infantile complexes of the primitive mind in forms of animism. What this structure of explanation excludes is the possibility of experiencing the 
uncanny during childhood. Instead, childhood itself becomes the repressed which returns, with uncanny effect, in adulthood.

In introducing his essay, Freud airily remarks that he has not made a very thorough examination of the literature, "especially the foreign literature," on the topic (219). Despite the immense critical literature on the concept of the uncanny, post-Freud, scholars have tended to follow his example in not exploring prior models.1 By placing Freud's theories in the context of nineteenth-century psychology and anthropology, I aim to cast new light not only on Freud's constructions of the uncanny, but also the role played by the figure of the child in the cultural imaginary of the era. In the first section of the essay, I explore theorisations of the uncanny within childhood itself in the work of one of the leading figures in early child psychology, James Sully. The second section, conversely, opens with the startlingly uncanny image of the severed head of the child, as a model for the unconscious workings of the mind. The uncanny, Royle has argued, is a form of making strange, and psychoanalysis is itself a form of the uncanny in that it "brings to light things that should have perhaps remained hidden or repressed" (24). In bringing to light the hidden history of the teraph in late Victorian culture, I highlight the limitations of an Oedipal model which focuses on the murderous instincts of 
childhood, but pays little heed to adult projections of violence onto the figure of the child.

\section{James Sully and the Uncanny within Childhood}

James Sully was a significant figure in the literary and scientific circles of late nineteenth-century England. A close friend of George Eliot and G. H. Lewes (whose posthumous Principles of Psychology he helped Eliot complete), and of Leslie Stephen and his circle, he was also the leading light in the development of child psychology in England, and responsible for the institution of the first psychology laboratory in the country (Valentine). Sully's major work, Studies of Childhood (1895), was owned by Freud (in the German translation of 1897), and cited by him in both "Infantile Sexuality" (174) and Totem and Taboo (90). Like Freud, Sully was deeply influenced by emerging models of childhood in post-Darwinian evolutionary biology and anthropology. Whilst the analogy between the child and savage was used in the Romantic era to theorise stages of historical development, it was only in the late nineteenth century that such theories were given scientific articulation in a range of emerging disciplines, including child psychology (Rowland 13-16, Steedman). Sully subscribed to both biological and cultural theories of recapitulation: the child, he declared, was "a monument of his race", and "a key to its history" (9). In particular he draws on the parallels between the child and 
primitive mind as articulated by anthropologists John Lubbock (1870)and Edward B. Tylor $(1865,1871)$ in their theories of animism -- a concept which was foundational for theories of the uncanny (104). In his questionings, and puzzlements, and projections of life and agency onto external objects, the child, sully argues, exhibits a "form of anthropomorphism which runs through the whole of primitive thought" (81). Far from being dismissive, however, and relegating the child to an undifferentiated world of the primitive, sully draws on the insights of anthropology to produce a subtle study of the stages of child development.

Sully's first discussion of the uncanny comes, significantly, when he is considering "the first stages of development of the idea of self" with reference to "the experience of the mirror "(112) in what appears to be a direct anticipation of Lacan. Although Lacan's theories of the mirror phase are often traced to the work in animal behaviour of Henri Wallon in the 1930s, there was considerable discussion of the role of the mirror in animal and child development in the nineteenth century, including Darwin (28990), and the German leader of the field, Wilhelm Preyer (190208). Sully seems to be the first psychologist, however, to link a child's identification of its self in the mirror both with a movement into language, and a sudden shift into a new form of self-awareness and understanding. He notes that the infant does not initially identify the image in the mirror 
with its self; this is a development which usually accompanies the advance in language to the difficult forms of " $I$ ", "me" and "mine." Sometimes, Sully observes, "the apprehension of the existence of a hidden self distinct from the body comes as a sudden revelation. . . . Such a swift awakening of selfconsciousness is apt to be an epoch-making and memorable moment in the history of the child" (114). Part of this process of coming to an understanding of a "hidden self," distinct from the body, can be linked to responses to shadows: "Some children on noticing their own and other people's shadows on the wall are afraid as at something uncanny" (113). Sully links this experience of the uncanny to "the development, in the early thought of the race, of the animistic conception that everything has a double nature and existence" (113). His examples are of George Sand as a child reflecting on an echo, and the young Hartley coleridge distinguishing between "a picture Hartley and a shadow Hartley" (113). Anticipating Jentsch and Freud on the uncanniness of dolls, sully highlights the ways in which children can think through their own forms of existence in relation to dolls. Thus he records one child who, when playing with her dolls, asked her mother, “Mother, am I real, or only a pretend like my dolls?" (114).

Sully also addresses the difficulty a child has in comprehending a world in which it does not exist. In a passage referenced by Freud in Totem and Taboo (90), Sully 
remarks that "the child is naturally a Berkeleyan," in that ideas or objects only exist if he perceives them (118). Such idealism is related to what Freud terms, in Totem and Taboo, the "omnipotence of thoughts" which is, he argues, "the principle governing magic" and "the animistic mode of thinking" (85). In this formulation Freud is drawing on E. B. Tylor's definition of magic in Primitive Culture as "mistaking an ideal connection for a real one," as well as the language of his patient, the "Rat man," who used this phrase to define "the strange and uncanny events" of his experience when, it seemed, he only had to think of something and it would happen $(79,86)$. Sully's discussion of the uncanny, as experienced in childhood, similarly focuses on the transformative powers of the mind. He notes, for example, a child's fear of the "uncanny aspect" of a toy elephant which shook its head:

The close simulation of a living thing by what is known to be not alive is disturbing to the child as to the adult. He will make his toys alive by his own fancy, yet resent their taking on the full semblance of reality. In this he is a born idealist and not a realist. (206)

Although Sully does not reference it, Dickens's short story "A Christmas Tree" (1850) comes to mind, in which Dickens describes his horror of the "infernal snuff-box" from which sprang "a demoniacal Counsellor" or the "dreadful mask", knowledge of whose mere existence was "sufficient to awake me 
in the night all perspiration and horror" (289-90). As in Sully's analysis, the child's imagination animates these uncanny objects, which then take on a threatening aspect which cannot be controlled.

Sully's main discussion of the uncanny comes in his chapter on Child Fears. Interestingly, given his evolutionary bent, he rejects Darwin's suggestion in his “Biographical Sketch" (288) that children's fears are inherited from their ancestors (208). Instead he makes their fears, and feelings of the uncanny, an intrinsic element of child development and immediate experience. His primary illustration of the uncanny is that of a baby who had not been upset by going to a strange nursery, yet cried after returning to its own, following an absence. He speculates:

Perhaps the child's partial recognition was accompanied by a sense of the uncanny, like that which we experience when a place seems familiar to us though we have no clear recollection of having seen it before. (200)

Babies, he suggests, experience the uncanny if "familiar things [are] seen after an interval" or surroundings undergo partial alteration (200). Unlike the Freudian theory, the explanation refers neither to inherited memories, nor to the resurgence in adulthood of long-buried feelings, but rather to the uncanny as a characteristic experience of childhood, as 
the infant struggles to come to terms with an environment which is both familiar and constantly changing.

Sully's examples are those also taken up by Jentsch and Freud. Where they consider the life-size doll in Hoffmann's "The Sandman," Sully focuses on the "well-marked recoilings of children from odd uncanny-looking dolls" (204). Here it is the "ugly transformation of something specially familiar and agreeable which excites the feeling of nervous apprehension," just as grimaces which transform the "homely and assuring face" into something mysterious, also evoke feelings of the uncanny and fear in the child (204-205). Life Freud, Sully also defines the uncanny in opposition to the homely (his usage here meaning familiar, rather than plain, or unattractive). Sully argues, in similar vein, that fear of animals can be traced not to ancestral memories, but to the "uncanny and savage-looking forms" of animal faces which can appear as "ugly distortions of the human face and figure" (211). Once again, the focus is on the juxtaposition of the familiar and the unfamiliar as a cause of the nervous fears aroused by the uncanny. It is a form of experience which is fundamental to child development: as the experiential base gradually broadens, there will be fewer shocks of the unfamiliar .

In keeping with his focus on the child's animistic tendencies, sully explores the child's fear of shadows, and of the dark. He draws here on a literature, which had been 
developing since Lamb's essay of 1821, "Witches and other Night-Fears," that stressed the vulnerability of the child to fear, and the intensity of suffering of the sensitive child (examples would be the scene in the red room in Jane Eyre, Harriet Martineau's autobiography, or a growing body of medical literature which insisted that it was cruelty to leave a child in a room without a light). ${ }^{3}$ Sully tracks the animistic tendencies of both children and animals in their fears of what appear to adults harmless objects -- a leaf whirling in the wind, or a floating feather, which to a child or a horse can appear "something exceptional and uncanny, that is to say, unintelligible, and so smacking of the supernatural." Unexpected "signs of life," whether movement or sound, take on "an uncanny aspect" (205-6). Shadows partake of this realm of the uncanny. Sully draws here on his friend Robert Louis Stevenson's poem, "Shadow March," from A Child's Garden of Verses (1885):

All around the house is the jet-black night:

It stares through the window-pane;

It crawls in the corners, hiding from the light, And it moves with the moving flame.

Now my little heart goes a-beating like a drum, With the breath of the Bogie in my hair; And all round the candle the crooked shadows come, 
And go marching along up the stair.

The shadow of the balusters, the shadow of the lamp, The shadow of the child that goes to bed All the wicked shadows coming, tramp, tramp, tramp, With the black night overhead.

As Julia Reid has shown (111-37), Robert Louis Stevenson was deeply interested in anthropology, and in this poem he offers a perfect illustration of the child as an animistic thinker. The black night is a personified being, and the shadows are not cast by the candle, but come to menace both it and child. The poem also captures the way in which animism becomes overlain with the stern Calvinist theology of Stevenson's upbringing, as the child's terror of the shadow elides with terror of his own "wickedness," whilst his own footsteps become those of an evil external force. Like Sully, he is exploring how a child comes to its own sense of selfhood as it negotiates between its own bodily sense of being, and its responses to the external environment. As it grows older, these responses are refracted through a cultural overlay which the child in turn then transmutes within its own animistic forms of perception.

Developing his theory that the uncanny arises from the intrusion of the unfamiliar upon the familiar, sully argues that a child's fear of the dark is linked to a loss of 
familiar surroundings: "darkness, by extinguishing the world of visible things, would give to a timid child tenacious of the familiar home-surroundings a peculiarly keen sense of strangeness and of loneliness, of banishment from all that he knows and loves" (215). In this sensitive reading, sully captures the confused transposition of self and external world, whereby the veiling of familiar surroundings brings with it a sense for the child that he is the one who has undergone change, and been "banished" from his own realm. Darkness, Sully notes, can stimulate a child's imagination so that it can tend to materialise or reify the darkness (as seen in Stevenson's poem), with one child seeing it as a "crushing power" (216). He warns, not only against that old bugbear, nurses' tales, but also religious instruction, since one case suggested to him "that a child may take a strong dislike to being shut up in the dark with the terrible all-seeing God" (219). As in the Stevenson, Sully suggests that a child's tendency to animism, when overlain with a harsh form of Christian theology, can produce a state of overwhelming terror in the child. Sully does not belabour the point, but its juxtaposition of Christian and primitive religion operates its own form of defamiliarisation, turning Christianity, with its "all-seeing God," into a form of primitive animism, yet of a sterner cast, since we know that fear of this terrible God arises from the fact that the child has been told that its own "wickedness" will always be on view. Fear of the dark is 
compounded by fear of the self. Whilst Freud sees the uncanny as the resurgence of primitive behaviour patterns, sully suggests that supposedly more advanced forms of belief are themselves new forms of animism, which exert more terrifying and dominating forms of control. Viewed in this perspective, Freud's "super-ego" is a reification of the animistic vision of the "all-seeing eye".4

In contra-distinction to Freud, Sully argues that children, like animals and primitive people, all experience the uncanny, due to their shared fear of the new, or "neophobia" (221). Such fears are intensified for the child, however, by its powers of imagination. Sully paints a sympathetic portrait of the child as torn between curiosity and fear, the imagination acting as a power that can alleviate, but also powerfully intensify, terrors caused by the uncanny. Where Freud sees the uncanny as an experience of adult life, sully places it as the defining quality of early experience, when the child is constantly contending with the destabilising of familiar environments, and its own developing powers of imagination. Far from an upsurge of the primitive in adulthood which needs to be repressed, sully depicts the uncanny as a shared attribute of primitive and child life which needs to be nurtured as it opens out the possibilities of imaginative exploration.

Severed Heads: the child, the unconscious, and the uncanny 
Freud's worries about the resurgence of primitive instincts, which are projected onto the figure of the child, have some disturbing counterparts in earlier nineteenth-century culture, where images of the uncanny and the unconscious are linked not only to the figure of the child, but more specifically to the child as a victim of violence. Frances Power Cobbe, ardent feminist and campaigner against violence to animals, opens her influential essay on "Unconscious Cerebration" (Macmillan's Magazine, Nov. 1870) with a startling image of the unconscious :

The old Hebrew necromancers were said to obtain oracles by means of Teraphim. A Teraph was the decapitated head of a child, placed on a pillar and compelled by magic to reply to the questions of the sorcerer. (24)

The matter of fact statement makes the detail even more arresting; we are looking not just at a child's head, but a decapitated one, a word which brings with it a sense of excessive and gratuitous violence. And why did the necromancers turn specifically to the head of a child? In the ranks of the uncanny this must surely rate very high, with the disturbing overlaying of death and young life. This is not, it would seem, the head of some enemy captured in battle, but the result of a deliberate murder of an innocent child. The image serves, for Cobbe, as an illustration of a materialist theory of mind -- the idea that the mind can operate without 
an animating spirit; but its associative, symbolic reach moves well beyond the sphere of Victorian psychology explored in the essay.

As we have seen, both Jentsch and Freud located the uncanny in the confusion caused by an object on the borders of the animate and inanimate. Jentsch speaks of the horror aroused by the death's head, as "thoughts of latent animatedness always lie so close" (15). For women, children and dreamers, or those who are delirious, intoxicated, ecstatic or superstitious, "the head of a pillar. . . comes alive by means of hallucination" (13). In her recent work, The Severed Head: Capital Visions (2012), Julia Kristeva offers a meditation on the severed head in art and culture, taking as her starting point Freud's theory in Totem and Taboo that the origins of culture lie in the murder of the father by a band of brothers. For Kristeva, severed heads offer an experience of the sacred, and a way of overcoming death. Through them, she suggests, we learn that "the only resurrection possible may be . . representation" (vii). She finds the "birth of Homo religiosus and of his socius. Centered around the cult of the severed head" (19). Despite according the severed head such centrality in human cultural and social development, she does not discuss in the book either the teraph, or the decapitation of children's heads. To do so would be to fundamentally rework the significance of the Oedipal complex since we would be looking not at the 
murderous desires of children towards their mother or father, but rather the violence of adults against the child. Freud is of course also preoccupied by the figure of the severed head, most notably that of Medusa, which he links in his essay "Medusa's Head" (1922) to fears of castration (273-74;

Albrecht 27-50). He does not, however, consider the image of the severed head of a child. Indeed, there appears to be virtually no scholarship on this interpretation of the teraph, or its role within nineteenth-century culture. Before returning to Cobbe's use of the image to explain the processes of unconscious thought, I will, therefore, offer a brief sketch of the origins and significance of the idea as it emerged within Victorian culture.

Teraphim, or household gods, are frequently referred to in the Bible, the most well-known reference being probably Rachel's theft of her father's household gods in Genesis 30 where they are referred to simply as images. The OED (from 1911) defines teraphim as idols or images, which were "an object of reverence and means of divination," but has no explicit reference to a child's head. Nonetheless, the idea that teraphim could have been children's heads, amidst lapsed and idolatrous sects, appears to have had considerable currency in the nineteenth century. Cobbe, it should be noted, was writing at precisely the time when anthropological writings, and explorations of primitive forms of worship, were capturing the public's imagination. John McLennan's "The 
Worship of Animals and Plants," which Freud credited in Totem and Taboo with defining the theory of the totem (3), had recently been published in the Fortnightly Review (October 1869; February 1870) (to be followed by Herbert Spencer's "The Origin of Animal Worship" in May 1870). Such works, whilst not addressing the actual details of teraphim worship, set ideas of primitive animism and fetishism at the heart of contemporary debates about human development and psychology, arguing (against degenerationists) for a unity of human culture. Edward Burnett Tylor, the "father of anthropology," had set out his theories of animism in "The Religion of Savages" in the Fortnightly Review of 1866, paralleling the primitive instinct to endow inanimate nature with life not only with that of the child, but also the regular process of dreaming, "so closely does this conception fit with the ordinary phenomena of dreams and waking hallucinations" (73). Tylor also traces religious rites of sacrifice to the same roots in animism, gently hinting that vestiges of these earlier processes of thought could still be found in Christianity (78). T. H. Huxley, taking such ideas one step further in his two part essay "The Evolution of Theology: An Anthropological Study" (1886), suggested that anthropology was but a department of biology, and all religions, past and present, could be seen to be based on fetishism and "ghost theory." Undercutting optimistic theories of cultural progression, he argued that teraphim worship of the past was 
mirrored by current practices in Tonga, whilst the moral sense of the Egyptians of $19 \mathrm{C} \mathrm{BC}$, was seen in various respects to be superior to that of England in $19 C A D$.

Prior to this emergence of anthropological interest in the religions and cultures of the past, and the light they could shed on current social beliefs and practices, two literary texts appear to have been responsible for the wide cultural circulation of the idea that teraphim could have been children's heads: Southey's 1801 Romantic epic poem Thalaba the Destroyer, which was frequently reprinted during the century, and also adapted for children, and Charles Kingsley's novel Hypatia, or New Foes with an 0ld Face (1853) which shows clear influence from Thalaba. ${ }^{6}$ Both were romances preoccupied with the myths and supposed sorcery of the East, although Kingsley added his own brand of violent anti-Catholicism, conjoined with the casual anti-Semitism which permeated nineteenth-century culture. Although Hypatia was set in $5^{\text {th }}$ century Alexandria, its real subject of attack was the Victorian Roman Catholic church, which offended Kingsley's muscular Christianity. He announces in his Preface that his work celebrates the Christian and scientific metaphysic which battled against "that strange brood of theoretic monsters begotten by effete Greek philosophy upon Egyptian symbolism, Chaldee astrology, Parsee dualism, Brahminic spiritualism" (xiii); in other words, an indiscriminate mix of suspect Eastern practices. 
The novel is written in suitably sensationalist style. When the hero, the Christian monk Philammon, enters the abode of Miriam he meets a sight that chills his blood:

a bracket against the wall, on which, in a plate of gold, engraven with mystic signs, stood the mummy of an infant's head; one of those teraphim, from which, as Philammon knew, the sorcerers of the East professed to evoke oracular responses. (Ch. 19, 195) The same fascinated horror with Eastern sorcery was similarly present in Southey's Oriental romance, Thalaba, which, unlike Hypatia, had adopted a Muslim hero, its target being all forms of superstition and idolatry (including, as Fulford notes, within the Anglican church (viii)). Drawing on Beckford's Vathek, the Arabian Nights, and a whole host of works on the history of magic and religion, Southey constructed a tale full of sorcery. In keeping with the Gothic mode, when he comes to depict the teraph he increases its unsettling quality, making it now explicitly "A new-born infant's head," although the learned sources he cites in lengthy footnotes do not quite bear out this reading. ${ }^{7}$ His infant is a perfect exemplum of the uncanny, with dark, dead skin, and hairless skull: "only the eyes had life,/ They gleam'd with demon light" (Bk2, lines 26-36). The image is at once innocent and demonic, a child who is dead yet an oracle of the future.

Although Southey's original source was from the seventeenth century, there were many versions of this story 
circulating in the nineteenth century, most notably in updatings of William Whiston's very popular translation of the works of the first century Jewish historian, Flavius Josephus (first published 1737, but continuously reprinted in the $18^{\text {th }}$ and $19^{\text {th }}$ centuries), which carried an additional "Sequel to the History of the Jews." 8 For many nineteenth-century homes, Josephus functioned as a form of supplement to the Bible: Josephus is one of the motley (unread) collection of books on Featherstone's shelf in Middlemarch (I, 167), whilst the young, evangelical Mary Ann Evans, refusing on principle to attend the theatre whilst on a visit to London with her brother, bought herself a copy of Josephus instead (Cross, I, 32). Although the "Sequel" is strongly supportive of the Jewish cause, celebrating, in a mid-century edition, the Commons vote for Emancipation (885), it nonetheless offers extensive details of earlier times when Jews had fallen into idolatry, including an account from Rabbi Eliezer of the "abominable process," of creating a teraph from a child's head, and expecting the "ghastly object" to make "important revelations" (Ch. 14, p.648).9 Fascination with the uncanny and macabre aspects stands in uneasy relation to the celebration of the Jewish release from eighteen centuries of “thraldom and oppression" (885).

At the time that Cobbe was writing, horror at the "abominations" of early religious practices was in the process of being supplanted by anthropological fascination with the 
processes of cultural development, and particularly, the workings of animism and fetishism, in both the primitive, and the 'civilised' mind (see Logan, 89-114). Eliot, in The Mill on the Floss, had satirically explored Mrs Tulliver's devotion to her "Teraphim, or Household Gods," (Bk III Ch.2) and the forms of religion practiced in St 0gg's which appeared less "congruous with the mystery of the human lot" than a "vigorous superstition, that lashes its gods or lashes its own back" (248). Like Huxley, she questions any sense of moral progress. The growth of spiritualism, with its interest in forms of afterlife, fuelled often by a desire to hear a child speak from beyond the grave, added to all this mix (Oppenheim, 159-62). Tylor (1866) was quick to dismiss spiritualism as the re-emergence of savage forms of sorcery (85), whilst Cobbe's friend, the eminent psychologist W. B. Carpenter, attempted, in various articles during the 1870 s to place seemingly supernatural phenomena, such as mesmerism and spiritualism, in the light of scientific understanding of the inner workings of the mind.10 Just as Tylor was interested in dreams, and their parallels with primitive beliefs and religion, the rising sciences of both psychology and psychiatry were similarly preoccupied by primitive and supernatural beliefs and what they might reveal about the unconscious processes of the mind, whether in everyday actions, dreams, or extreme forms of behaviour which resembled primitive forms of religion, such as hysteria. 
Aspects of all these strands are brought together in my second example of the cultural reach of the image of the teraph: John William Waterhouse's painting, "Consulting the Oracle," (fig. 1) which was the hit of the 1884 Royal Academy Summer Exhibition (the Illustrated London News reproduced it in a double page spread). ${ }^{11}$ In the explanatory notes for the catalogue, probably drawn from Josephus, waterhouse outlined the history of the teraph"12: "The Oracle or Teraph was a human head, cured with spices, which was fixed against the wall, and lamps being lit before it and other rites performed, the imagination of diviners was so excited that they supposed that they heard a low voice speaking future events."13 Despite this display of scholarly authenticity, Waterhouse's commitment to historical accuracy only goes so far: he discretely censors the detail about the head being that of a child, and focuses instead on the state of emotional excitement of the young women gathered around the teraph. From that triumvirate of figures of the primitive and the uncanny -- women, children and savages -- Waterhouse selects a "savage" for his teraph.14 The head, on close inspection, appears of African origin, and of a size that directly mirrors the diviner's own; it is illuminated from behind by light reflected on a gold plate, as described in the "Sequel" of Josephus. Whilst the cupboard at the far right, with Torah scrolls and inverted menorah motif, hints at Hebraic associations, the setting appears loosely Eastern, as in 
Waterhouse's numerous other depictions of female worshippers or sorcerers.15 The diviner leans in so that the lips of the teraph almost kiss her cheek, creating a dramatic atmosphere of disturbing sensuality which spreads outwards, rippling through the assembled women. The Art Journal in its review picked up on this dramatic quality: "The terror, the hysteric awe of the women who are assembled to consult the Teraph are finely conceived. Their swollen features, glazed eyes, and a certain ecstatic insincerity are characteristic of this imaginative emotion" (211). Cosmo Monkhouse in the Academy similarly focuses on the "awe and expectation" of the young women as they await "the message of the diviner, who, with a face charged with a 'fine frenzy,' is standing with her ear applied to the hideous mummied head or Teraph." He notes that the "contrast between these two heads is a 'thrilling' one" (336). The composition calls attention to the relationship between the hideous quality of the head and female frenzy, as if the suppressed uncanny form of the infant is transposed directly onto the hysteric emotions of primitive femininity .

As the vocabulary of the reviews makes evident, with the references both to "hysteric awe" and "ecstatic insincerity," viewers readily positioned the painting in the context of contemporary discussions of female hysteria, rather than any particular religious practices. Waterhouse in creating the picture had been influenced by the French painter Jules 
Bastien-Lepage, who had attended lectures by Charcot, and starting with his picture of Joan of Arc listening to voices (1879), depicted a series of women in ecstatic or trance states, probably drawing from Charcot's published photographs.16 Charcot's fame had by this time spread to Britain. As an article by Jules Claretie, "Notes from Paris," in the Athenaeum (1883) observed, "One might suppose that the real president of the Republic was not M. Grévy, but Professor Charcot; and the asylum at Salpêtrière seems to have more influence than the Elysée" (345). This is, of course, a chain of influence that will reach forward to Freud, who spent the winter of 1885-86 attending Charcot's lectures, in the formulation of his theories on hysteria, and subsequent reflections on the uncanny. As the reception of Waterhouse's painting suggests, the teraph provided a bridge between anthropological explorations of earlier religious practices, and psychological explorations of the uncanny.

Frances Power Cobbe's use of the image of the teraph in "Unconscious Cerebration," is far less sensationalised; she deploys it to support her argument that it is possible to create a distinction between body and soul. Cobbe asks her readers to suppose that it might be possible "to make a human corpse speak . . . Further, let us suppose that the Teraph only responded to inquiries regarding facts known to the owner of the head while living, and therefore (it may be imagined) 
impressed in some manner upon the brain to be operated on" (24). The startling violence of the opening image is reduced and controlled, becoming in its now very limited nature an image of the self as propounded, Cobbe argues, by thinkers who argue that there is nothing beyond the workings of the material processes and functions of the brain. Cobbe herself is not a simple anti-materialist; her essay is indebted to the physiological psychology of her friend W. B. Carpenter who coined the term unconscious cerebration, and who in turn draws upon Cobbe's essay for inspiration in his own major work in the field, Principles of Mental Physiology (1874)(see Taylor, 100). In her discussions of "unconscious cerebration," and in a series of popular essays, including "Fallacies of Memory" (1866) and "Dreams as Illustrations of Unconscious Memory" (1871) Cobbe played a significant role in Victorian explorations of the inner workings of the mind.

"Unconscious Cerebration" is wonderfully insightful on the ways in which unconscious thought processes disrupt the even tenor of social intercourse, prefiguring what Freud was to term the psycho-pathology of everyday life. Cobbe outlines, for example, the case of a man whose "social existence is poisoned by his unconquerable propensity to say the wrong thing to the wrong person":

If he have an acquaintance whose brother was hanged or drowned, or scraped to death with oyster-shells, then to a moral certainty the subjects of capital 
punishment, the perils of the deep, and the proper season for eating oysters will be the topics selected by him for conversation during the awkward ten minutes before dinner. (33)

In this situation, in the absence of conscious control, the "unconscious brain, like an enfant terrible, is extremely veracious," speaking truths it would be better to suppress. The image of the severed head has been transmuted here into the more acceptable figure of the disruptive child, with wisdom beyond its years. In an intriguing, unstated association, however, the figure who is "scraped to death by oyster shells" recalls the famous death of the female philosopher and mathematician, Hypatia of Alexandria, who was the subject of Kingsley's novel, and who, in Gibbon's account, was stripped naked, butchered, and "her flesh was scraped from her bones with sharp oyster shells."17 Presumably this gruesome death of an acclaimed female intellectual, who had dared to challenge authority, had particular personal resonance for Cobbe, although displaced here into an anecdote of comic social ineptitude. The Kingsley link also reinforces the probability that his novel was the source for her opening reference to the teraph, suggesting unacknowledged chains of association between the sensational scenes of the novel, and her attempt to offer a scientised model of the unconscious mind. 
A marked change in tone occurs in the essay when Cobbe turns to confront directly her own disturbing experiences, and to address, significantly, the psychology of the uncanny: "Still more 'uncanny' and mysterious is the impression (to me almost amounting at times to torture) that we have never for years quitted the spot to which we have only that instant returned after a long interval." Such a delusion, she suggests, only arises "when we have undergone strong mental tension at the haunted spot" and our "unconscious cerebration has photographed the scene on our optic nerves" (32). The narrative shifts into a darker register as she attempts to grapple with the sense of perpetual imprisonment in a moment in the past, as forward movement in time is annulled, and the mind is dragged backwards, despite conscious awareness of delusion. In attempting to come to terms with her own experience of the uncanny, Cobbe extends her range of analogies beyond the teraph. The gothic resonances of haunting are combined with scientised references to photography and optic nerves as she seeks to find a language that can capture the ineradicable nature of the unconscious images and emotions stored within the mind.

In her next article, "Dreams as Illustrations of Unconscious Cerebration," Cobbe continued her theme, but this time, we are informed, with the advantage of a large postbag of readers' responses giving details of their own experiences of unconscious workings of the mind. Intriguingly, these are 
frequently violent, particularly with reference to children. Thus a woman who worked with pauper children dreamed that she took one, "doubled him up into the smallest compass, and poked him through the bars of a lion's cage" (521). This dream recalls Cobbe's observation in the earlier essay that "We commit in dreams acts for which we should weep tears of blood were they real, and yet never feel the slightest remorse. On the most trifling provocation we cram an offending urchin into a lion's cage (if we happen to have recently visited the Zoological Gardens)" (28). Association is acknowledged, but not responsibility. Passions, Cobbe suggests, which "never for a moment sullied our consciousness," nonetheless emerge in sleep. Thus "the woman who never yet voluntarily hurt a fly, chops a baby into mincemeat" ("Dreams," 522).

For the modern reader, steeped in Freudian models of analysis, her conclusions are perhaps surprising. It is the very distance between the conscious mind and these disruptive, unconscious processes which clearly demonstrates that the mind is quite distinct from the brain, and that the individual is therefore not morally responsible for the thoughts or feelings which arise from the unconscious: "Our dream-selves, like the Undines of German folk-lore, have no Souls, no Responsibility and no Hereafter" ("Unconscious Cerebration" 28). Almost perversely, it is the marked violence of the images of the unconscious mind, with all those mutilated children, which cause her to set aside its dreams and promptings as quite 
distinct from a conscious self. Indeed, the evidence "that our brains sometimes think without us" (37) merely confirms her belief in the separability of the material brain and the Soul or Spirit which will, unlike the Undines, have a Hereafter. Despite these reassurances, however, the dominant image that remains with the reader is that of the opening -the decapitated head of a child. The model of the mind is that of a murdered, mutilated child, compelled to continue to exist, and to answer questions at the sorcerer's command. Although Cobbe rejects this model of the mind as too limiting, her evidence for the freeplay of the unconscious mind offers us yet another model of violence to children, committed this time by an unconscious, absolved of all responsibility for its crimes.

\section{Freud: Children, Violence, and Baby-Killers}

In her interpretation of dreams, and determined refusal to trace any link between the violence of the images, and the conscious lives of the subjects, Cobbe seems to belong to an era that is decisively pre-Freudian. As Freud notes in "Moral Responsibility for the Content of Dreams" (1925) "one must hold oneself responsible for the evil impulses of one's dreams," since the ego cannot be separated from the id (133). Yet, there are unexpected parallels between the two. Freud frequently instances dreams of parents who feel violence 
towards their children. Thus in "The Archaic Features and Infantilism of Dreams" (1916) he instances a woman who dreams of her 17 year old daughter lying dead in a box, and traces this to a forgotten wish during her early days in pregnancy, when, "in a fit of rage after a violent scene with her husband she had beaten with her fists on her body in order to kill the child inside it" (202).19 Similarly the dream of a father which, in Freud's view, " justified the interpretation that he wished for the death of his favourite eldest child" (202), is traced back to a time when the child was still an infant and the father had wished him dead.20 The wish-fulfilment of the dream is displaced onto an earlier, forgotten experience, and in association with what Freud seems to regard as an almost pre-human state of infancy, either as foetus, or infant, when, as he observes in the Psychopathology, the child "had been so small that its father had not yet had any reason to take an affectionate interest in it" (188). The text seems to endorse this process of reasoning, placing early infancy outside the radius of parental love. Freud's own arguments seem to proceed by association, so that we move from the violence of a parent's dreams, linked to a child in infancy, to the origin of all "evil impulses," which he also traces to infancy. Seeking to find an explanation for the "wickedness in human nature" Freud turns to childhood itself, when egoism, he argues, is dominant and the child is ruled by hatred and murderous thoughts towards its siblings and father (the 
Oedipal complex) or mother, as well as incestuous desires ("Archaic Features" 204). He concludes, therefore, with reference to the violence of adult dreams, that "what is unconscious in mental life is also what is infantile." Thus, The strange impression of there being so much evil in people begins to diminish. This frightful evil is simply the initial, primitive, infantile part of mental life, which we can find in actual operation in children, but which, in part, we overlook in them on account of their small size, and which in part we do not take seriously since we do not expect any high ethical standard from children. (210-11)

Horror at the "evil" in adults is thus assuaged, by displacement of guilt onto the child, who is capable of "frightful evil."

The extreme nature of the language is striking: Freud, the theorist of polymorphous perversity, does not, as one might expect, refer to a period of amorality, prior to the emergence of conscience and internalised social values, but rather employs, repeatedly, the emotive and moralised term, "evil" (böse). In a rhetorical move which parallels that of Cobbe, he suggests that if "evil impulses in dreams are merely infantile phenomena . . . we need not, if we are reasonable, be ashamed of these evil dreams" (211). Both Cobbe and Freud suggest that it is the violence of the dreams themselves that absolves the adult dreamer from guilt; but Freud adds a 
further layer of displacement, by blaming such violence on the child. Cobbe's image of the unconscious as a child's severed head is matched and inverted by Freud, who makes the child not the victim but rather the instigator of violence. Dreams, like the uncanny, conjoin past and present, and in the association of the unconscious with childhood, we are returned to the image of the teraph, with its uncanny mixing of death and life, passion and stasis, wisdom and emptiness.

In Freud's analysis of children's dreams we find a further, disturbing projection of adult violence onto the child. Freud insists that all his female patients have dreamt of the death of their siblings. When one claims "to my astonishment" not to have experienced such dreams, he quickly uses a dream she recounts from when she was four to prove his point: "A flock of children, all her brothers, sisters, and cousins, were romping in a meadow. Suddenly they grew wings, flew up in the air, and were gone." Freud interprets this dream, not unreasonably, as a dream that all her siblings have died: "Our little angel-maker is left alone - think of it! the only one left after such a great flock!" (Interpretation of Dreams, ed. Robertson, 195). The interpretation, in this recent translation by Joyce Crick, is relatively benign: the child might wish to be alone, but not to actively slaughter its siblings. But a footnote alerts us to the fact that the original German "Engelmacherin," is "also the vulgar term for an abortionist" (429 n.195). In the Standard Edition, there 
is no such delicate attention to readers' sensibilities; instead the child is described as "our little baby-killer" (254). By thus figuring the child itself as a shady abortionist, Freud once again inverts the social order; the destruction of new life is symbolically associated not with adult crimes, but with the "evil" which emanates from the primitive instincts of the child.

Freud, like Cobbe and Sully, was working within a cultural environment in which conflicting attitudes to childhood - old Testament visions of the child as born in sin, or New Testament versions of childhood innocence - were reconfigured in the light of emerging anthropological thought. Freud, in his interpretation of primitive instincts, follows a route more aligned with old Testament versions of childhood (albeit without a strident Victorian moral overlay), whilst sully, drawing on a similar set of anthropological theories, produces a vision of childhood, and its relations to dreaming and the unconscious, which has more in common with New Testament understandings. Following Cobbe's essays on dreams and the unconscious in 1870-71, Sully published "The Laws of Dream Fancy" in the Cornhill (1876) where he suggested that in dreams we return to the "undeveloped mental condition of infancy" (555). Revisiting the topic twenty years later in "The Dream as a Revelation," (1893) he offers a far more sophisticated interpretation, which was to influence Freud. 
Dreaming, he suggests, brings about a reversion to sensation and instinct, although not just a retrogression to the primitive. Rather, dreaming offers a revelation since it "strips the ego of its artificial wrappings and exposes it in its rude native nudity" (358). What is exposed, however, is not an unsavoury mix of murderous and sexual impulses, but a healthy absorption in bodily sensation, which can take us to the "luxuriant splendour" of the senses experienced in childhood (359). Again anticipating Freud, Sully suggests that dreams "have more to do with remote than with proximate events." This "reversion of consciousness to the remote halfforgotten past" enables the mind to recover our alternate or former personalities, since we should not, he suggests, see ourselves as just one single personality (360). These "undeveloped, rudimentary selves belong to the hidden substrata of our mental being" (363) which can be revealed within dreams whose "chaotic aggregations" actually contain a "dream-inscription" that can be interpreted. In a passage cited by Freud, he suggests that, "like some palimpsest, the dream discloses beneath its worthless surface-characters traces of an old and precious communication." (364; Interpretation of Dreams, SE, 135). The message is "precious" since, in the artificial exchanges of social life, "Much that is deepest and most vital in us may. . . be repressed and atrophied" (363). 
Contrary to Freud, Sully locates the best of selfhood in the realm of the repressed. The primitive world of childhood sensation to which he reaches back is a form of idyll: the play of appetite is balanced by that of "the unstinting generosity of youth" and the creative vision of the child (364). Both Sully and Freud set off from the same starting point: the child as the expression of both individual and phylogenetic history, to which dreams can offer the key. Yet their diverse conceptions of childhood give rise to very different models: where Freud's child is a figure of murderous instincts and evil desires, requiring the construction of "screen memories" to protect the adult from both ownership and responsibility for these desires (Psychopathology, ch.4), Sully's child, by contrast, is a healthy sensualist, revelling in "the delicious fullness of childish sensation" (364)(seemingly without, it should be added, any evident sexual content), to which adults can only return in their dreams. Whilst Freud, in the figure of the child as abortionist, tipped over into a form of aggressive displacement, Sully turned to a somewhat idealised vision of childhood, not fully in keeping with the more subtle and nuanced analysis of child fears he offered in studies of Childhood.

Freud, Sully and Cobbe were all working in a nineteenthcentury cultural milieu which sought to understand the self through the workings of unconscious processes of the mind, 
which were in turn linked associatively with ideas of childhood, primitive impulses, and the uncanny. As we have seen, these ideas, in various forms, permeated psychological, psychiatric, and anthropological thought of the period, as well as literary and artistic culture more generally. In contemporary scholarship, Freud's construction of the uncanny has become, as Nicholas Royle ably demonstrates, a key theoretical tool for cultural analysis, whether in Kristeva's construction of learning "how to detect foreignness in ourselves," Bloom's understanding of the sublime, or Derridean deconstruction (Royle, 7, 14-15, 25). For Royle, the uncanny is a mode of questioning everyday life, from issues of "otherness" in relation to "sexuality, class, race, age, imperialism and colonialism" through to emerging technologies (23). If we turn Freud's making strange back upon itself, however, we expose a troubled centre. As the comparison with Sully's work reveals, there were different potential models for the uncanny, associated with contrasting models of childhood. Sully, by focusing experience of the uncanny on normative processes of child development, produced a positive model of growth, and human development. Freud, by contrast, excluded the child itself from experience of the uncanny; it becomes rather, a figure of the unconscious -- the repressed primitive desires which return to disrupt adult life. In a racist elision, childhood becomes the threatening "other". 
Unlike Sully and Freud, Cobbe does not address theories of the uncanny directly, but her uneasy engagement with the uncanny figure of the teraph as a model for the mind opens up the unsettling associations around childhood and the primitive which underpinned the imperialist mentality of the era. Cobbe's essay on "Unconscious Cerebration," in which the child becomes the very embodiment of both the unconscious and the uncanny, anticipates strands within Freudian thought. The image of the teraph, however, also draws attention to a central absence within Freud's work. The severed head of a child, which is both dead and alive, inanimate yet oracular, no longer present yet with access to both past and future, is by Freud's definition a uniquely uncanny figure. Yet it speaks, not, as in Freud's analysis of the severed head, to the child's desire for the death of the father, but rather to the murder of a child. Freud's theory of the uncanny opens up multiple avenues for cultural analysis, yet it harbours its own repressions, focused around the figure of the child. Like the teraph, the child in Freudian theory is at once feared primitive "other," and the source of self-knowledge, the oracle to which we need to turn to understand ourselves. Such constructions have at their heart, however, a form of violence towards the child, enacted not in crude physical measure, but in forms of construction and displacement. As the nexus of the primitive within man, the child is made to carry the burden of responsibility for the inadmissible 
desires of adulthood. It is a model very much of its time; but as Sully's work reveals, there were other possibilities -alternate constructions both of the child and the uncanny which opened up more positive interpretations both of history and selfhood.

My thanks are due to Laura Marcus and to Martin Goodman, President of the 0xford Centre for Hebrew and Jewish Studies, for their suggestions and comments on the paper; to Tim Fulford for his advice on Southey; to Franziska Kohlt for advice on translations of Freud's original terms, and to Carol Jacobi at the Tate for her support of my work on "Consulting the oracle".

1. The most definitive work on the uncanny in relation to culture is Nicholas Royle (2003). Carolyn Steedman(1995), has an excellent chapter on childhood and the uncanny which focuses on Goethe's child-figure, Mignon, in the light of Freudian concepts of the uncanny.

2. The reference in Totem and Taboo is quoted from R. R. Marett, "Pre-Animistic Religion," Folk-Lore 11 (1900): 178. Freud's copy of James Sully, Untersuchungen über die Kindheit, (1897) is held at the Augustus C. Long Health Sciences 
Library, Columbia University. Susan Sugarman (2010) offers a short discussion of sully and the uncanny (68-70).

3. For a development of these arguments see chapter 2 of my book, The Mind of the Child, (2010) and pp. 283-85 for a brief discussion of the uncanny.

4. Freud notes in The Ego and the Id (1923), that the superego actually originated from the experiences that led to totemism (38).

5. Kingsley (1877) noted in a letter of December 1848 that prior to The Saint's Tragedy (1848) he had not written poetry "but from my childhood had worked at poetry from Southey's 'Thalaba', Ariosto, Spenser, and the 'Old Ballads', through almost every school, classic and modern ..." (186).

6. Hypatia was originally serialised in Fraser's Magazine between January 1852 and April 1853.

7. In his lengthy note Southey records: "The manner how the Teraphim were made is fondly conceited thus among the Rabbies. They killed a man that was a first born son, and wrung off his head, and seasoned it with salt and spices, and wrote upon a plate of gold, the name of an uncleane spirit, and put it under the head upon a wall, and lighted candles before it and worshipped it. Godwyn's Moses and Aaron. In Rabbi Eleazer, it is said to be the head of a child" (204). See also Bk 10, line 284, and Southey's note (289-290). Fulford identifies Southey's sources as Thomas Godwyn, Moses and Aaron, or Civil and Ecclesiastical Rites used by the Ancient Hebrews (1625), 
and Abraham Eleazar, R. Abrahami Eleazaris Uraltes Chymisches Werke (Erfurt, 1735), the latter possibly from Gabriel Naudé, The History of Magic, trans. John Davies (London, 1657), 2489, which Southey cites directly in his notes on brazen images and teraphim, 289-290 (334).

8. Simon Goldhill (2011) notes that 'between 1801 and 1901 over 200 separate editions of Whiston's translation of Josephus were published' (279, n. 71).

9. John Brown's very popular A Dictionary of the Holy Bible, (1810), which went through many editions, offers a very similar account, drawn from Rabbi Eliezer, of the slaughter of the first-born child, and the use of its head as a form of oracle, under the entry for teraphim (II, 561).

10. See, for example, "On the Psychology of Belief," (1873)and "On the Fallacies of Testimony in Relation to the Supernatural" (1875), where he argues that "The faith placed by the Heathen as well as the Jewish world, in dreams, visions, trances etc, has thus its precise parallels in the present day" (p.285), as well as his essays collected in Mesmerism, Spiritualism, etc, (1877).

11. The work was bought by Henry Tate, and is in the collection at Tate Britain. For details on the work see http://www.tate.org.uk/art/artworks/waterhouse-consulting-theoracle-n01541/text-summary.

12. As Goldhill has noted, Waterhouse directed the viewers of his 1887 painting "Mariamme leaving the Judgement Seat of 
Herod" to "see Josephus," (47) so it is probable that his source for this painting was also The Antiquities of the Jews. 13. The entry (for painting 559) is unusual; most entries do not have any text apart from title. Where text is given, it is usually a poetic quotation. For a discussion of the painting, see Peter Trippi, J.W. Waterhouse (2002), 60-64. 14. The details of the head are not particularly clear in the reproduction. The painting is currently held in the Tate Gallery store, and I am indebted to curator Carol Jacobi for her help in arranging a private viewing, and also for discussing the painting with me.

15. Waterhouse had painted an earlier scene, "The Household Gods," (c. 1880), also Eastern in setting, which had had none of this emotional drama, but was rather domestic in orientation. He was to return again and again, however, to the figure of the entranced female, and also to the female diviner, as in the more famous work, "The Magic Circle" $(1886)$.

16. Trippi (60) notes that Bastien-Lepage first exhibited in London in 1878, and had rapidly developed a following in the artistic community. For a discussion of him as "Painter and Psychologist," see Brownell (1883). Charcot published

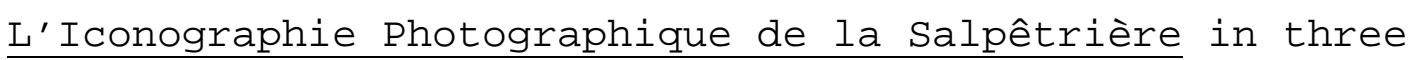
volumes, 1877-80.

17. Edward Gibbon, The Decline and Fall of the Roman Empire (ch. 47). In Kingsley's account of her death, the mob are 
depicted bearing down upon her with flints and shells, before her dress is ripped into shreds, and we are offered a voyeuristic image of her rising "to her full height naked, snow-white against the dusky mass around" before she is finally struck down (321-2).

18. The dream is discussed at greater length (including the detail about the box) in The Interpretation of Dreams (ch. 4), where the age is given as 15 .

19. The original case is given in "Bungled Actions" (1901)in The Psychopathology of Everyday Life (188).

Works Cited

Anon., "The Exhibition of the Royal Academy." Art Journal Jul. 1884: 211.

Brown, John. A Dictionary of the Holy Bible, 2 vols. Berwick: W. Gracie, 1810 .

Brownell, W. C. "Bastien-Lepage: Painter and Psychologist." The Magazine of Art 6 Jan. 1883: 265-271.

Carpenter, W. B. "On the Psychology of Belief." Contemporary Review 23 (Dec. 1873): 123-45.

-... “On the Fallacies of Testimony in Relation to the Supernatural." Contemporary Review 27 (Dec. 1875): 279-95.

-... Mesmerism, Spiritualism, etc, Historically and

Scientifically Considered (London: Longmans, Green, 1877). 
Charcot, Jean-Martin. L'Iconographie Photographique de la

Salpêtrière. Paris: Progrès Médical, 1877-80.

Claretie, Jules. "Notes from Paris." Athenaeum 17 March 1883: $345-46$.

Cobbe, Frances Power. "Dreams as Illustrations of Unconscious Cerebration." Macmillan's Magazine 23 (April 1871): 512-23.

-... "The Fallacies of Memory." Galaxy 1 (1866): 149-62.

-.-. "Unconscious Cerebration. A Psychological Study." Macmillan's Magazine 23 (Nov. 1870): 24-37.

Cross, J. W. George Eliot's Life as Related in her Letters and Journals. Cabinet Edition, 3 vols. Edinburgh and London: William Blackwood, 1878-80.

Darwin, Charles. "A Biographical Sketch of an Infant." Mind: A Quarterly Review of Psychology and Philosophy 2 (1877): 285 94.

Dickens, Charles. "A Christmas Tree." Household Words 2 (21 Dec. 1850): 289-95.

Eliot, George. The Mill on the Floss, ed. by Sally Shuttleworth. 1860: London: Routledge, 1991.

--. Middlemarch. 1871-72: 3 vols. Cabinet Edition:

Edinburgh and London: William Blackwood, 1878-80.

Freud, Sigmund. "The Archaic Features and Infantilism of Dreams," in Introductory Lectures on Psychoanalysis. The 
Standard Edition of the Complete Psychological Works, Vol. 15, ed. James Strachey. London: Vintage, Hogarth Press, 2001.

--. The Ego and the Id and Other Works. Standard Edition,

Vol. 19, ed. James Strachey. London: Vintage, Hogarth Press, 2001.

-.-."Infantile Sexuality," in A Case of Hysteria, Three Essays on Sexuality, and Other Works. Standard Edition, Vol. 7, ed. James Strachey. London: Vintage, Hogarth Press, 2001.

-.-. The Interpretation of Dreams, Standard Edition, Vol 4, ed. James Strachey. London: Vintage, Hogarth Press, 2001. --. The Interpretation of Dreams, trans. Joyce Crick, ed. Ritchie Robertson. Oxford: Oxford University Press, 1999. -... "Medusa's Head," in Standard Edition, Vol. 18, ed. James Strachey. London: Vintage, Hogarth Press, 2001.

-.. "Moral Responsibility for the Content of Dreams," in Standard Edition, Vol. 19,_ed. James Strachey. London: Vintage, Hogarth Press, 2001.

-- . The Psychopathology of Everyday Life. Standard Edition, Vol. 6, ed. James Strachey. London: Vintage, Hogarth Press, 2001.

-.. Totem and Taboo, and Other Works; Standard Edition, Vol. 13, ed. James Strachey. London: Vintage, Hogarth Press, 2001. 
-... "The Uncanny", in An Infantile Neurosis and Other Works;

Standard Edition, Vol. 17, ed. James Strachey. London:

Vintage, Hogarth Press, 2001.

Gibbon, Edward. The Decline and Fall of the Roman Empire, ed.

J. B. Bury, 7 vols. $2^{\text {nd }}$ edn. London: Methuen, 1900-02.

Goldhill, Simon. Victorian Culture and Classical Antiquity.

Princeton: Princeton University Press, 2011.

Huxley, T. H. "The Evolution of Theology: An Anthropological

Study." The Nineteenth Century 19 (1886): 346-65; 485-506.

Jentsch, Ernst. "On the Psychology of the Uncanny (1906)",

trans. by Roy Sellars, Angelaki: Journal of the Theoretical

Humanities 2 (1996): 7-23.

Kingsley, Charles. Hypatia, or New Foes with an Old Face.

1853; London: Macmillan, 1888.

Kingsley, Frances Eliza, ed. Charles Kingsley, His Letters and Memories of his Life. 1877: Cambridge: Cambridge University Press, 2011 .

Kristeva, Julia. The Severed Head: Capital Visions. New York: Columbia University Press, 2012.

Lamb, Charles. "Witches and other Night-fears", in The Works of Charles and Mary Lamb, ed. E. V. Lucas, 2 vols. London: Methuen, 1903; repr. New York: AMS Press, 1968. 
Logan, Peter Melville. Victorian Fetishism: Intellectuals and Primitives. Albany: State University of New York Press, 2009. Lubbock, John. The Origin of Civilisation and the Primitive Condition of Man. London: Longmans, Green and Co., 1870.

John McLennan, "The Worship of Animals and Plants."

Fortnightly Review 6 (Oct. 1869): 407-27; (Nov. 1869): 562-82; (Feb. 1870): 194-216.

Marett, R. R. "Pre-Animistic Religion." Folk-Lore 11 (1900): $162-184$.

Monkhouse, Cosmo. "The Royal Academy," Academy 10 May 1884): 336.

Oppenheim, Janet. The Other World: Spiritualism and Psychical Research in England, 1850-1914. Cambridge: Cambridge University Press, 1985.

Preyer, Wilhelm. The Mind of the child. Part II: The Development of the Intellect. New York: D Appleton, 1895.

Reid, Julia. Robert Louis Stevenson, Science, and the Fin de Siècle. Basingstoke: Palgrave Macmillan, 2006.

Rowland, Ann Wierda. Romanticism and Childhood: the Infantilisation of British Literary Culture. Cambridge:

Cambridge University Press, 2012.

Royle, Nicholas. The Uncanny. Manchester: Manchester University Press, 2003. 
Shuttleworth, Sally. The Mind of the Child: Child Development in Literature, Science and Medicine, 1840-1900. 0xford: Oxford University Press, 2010.

Southey, Robert. Poetical Works 1793-1810. Volume 3: Thalaba the Destroyer, ed. Tim Fulford. London: Pickering and Chatto, 2004.

Spencer, Herbert. "The Origin of Animal Worship." Fortnightly Review 7 (May 1870): 535-50.

Steedman, Carolyn. Strange Dislocations: Childhood and the Idea of Human Interiority 1780-1930. London: Virago, 1995.

Stevenson, Robert Louis. A Child's Garden of Verses. London: Longmans, Green and Co, 1885.

Sugarman, Susan. Freud on the Psychology of Ordinary Mental Life. Plymouth: Rowman and Littlefield, 2010.

Sully, James. Studies of Childhood. New edn. London: Longmans, Green and Co, 1896.

-.-. Untersuchungen über die Kindheit, trans. J. Stimpfl.

Leipzig: Ernst Wunderlich, 1897.

-.-. "The Dream as a Revelation." Fortnightly Review 53 $(1893): 354-365$.

--.. "The Laws of Dream-Fancy." Cornhill Magazine 34 (1876): $536-555$. 
The Exhibition of the Royal Academy of Arts, 1884. London:

Printed for the Royal Academy by William Clowes and Sons, 1884.

Taylor, Jenny Bourne and Sally Shuttleworth, Embodied Selves: An Anthology of Psychological Texts, 1830-1890. 0xford: 0xford University Press, 1998.

Trippi, Peter. J.W. Waterhouse. London: Phaidon Press, 2002. Tylor, Edward Burnett. "The Religion of Savages." Fortnightly

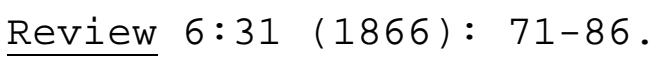

-- . Researches into the Early History of Man and the Development of Civilisation. $1865 ; 2^{\text {nd }}$ edn., London: John Murray, 1870 .

--. Primitive Culture. London: John Murray, 1871.

Valentine, Elizabeth R. "The Founding of the Psychological Laboratory, University College London: 'Dear Galton ...Yours truly, J. Sully', History of Psychology 2 (1999):204-18. Whiston, William. "Sequel to the History of the Jews; continued to the Present Time." in The Complete Works of the Learned and Authentic Jewish Historian, Flavius Josephus, the Jewish Historian. c. 1850, J. and F. Tallis. rprt: Green Forest, Ar.: New Leaf Publishing, 2008. 
